\title{
'God's Golden Acre for Children': Pastoralism and Sense of Place in New Suburban Communities
}

\author{
Mary P. Corcoran \\ [Paper first received, August 2008; in final form, July 2009]
}

\begin{abstract}
This paper is based on an empirical case study of four suburbs in the Dublin city hinterland. It is argued that pastoral ideology plays an active role in constituting these new suburbs and helps to inculcate a sense of place. This sense of place in turn helps to cement social embeddedness which acts as a bulwark against isolation and alienation. Pastoral ideology is invoked by suburbanites even when the pastoral dimension of the suburb is under threat or has disappeared. The village or 'main street' acts as an important anchor for new suburban residents as does the surrounding 'rural' landscape and their own collective memories. However, the study reveals a gap between how some newer suburbs are represented and imagined, and how they are experienced in everyday life. This raises questions about the long-term viability of suburbs that lack a sense of place.
\end{abstract}

\section{Introduction}

Existing scholarship has shown that the quality and nature of urban life depend in part on the way residents relate to their urban or suburban environment (Gans, 1962, 1968; Fischer, 1982; Hummon, 1992; Varenne, 1993; Bonner, 1997). This suggests that there is a dynamic process at work in suburbs. Residents act as agents who shape their immediate environment and the latter in turn shapes the parameters of residents' actions across space and time. Borer has described the processual element of urban living in terms of an urban culturalist perspective that may be fruitfully adapted for use in the suburban context. He suggests that an exploration of the lived culture of cities

offers a window into the ways that people use places as part of their cultural repertoires and how those repertoires can affect a city's social and physical environment (Borer, 2006, p. 174).

This can be looked at, for example, from the point of view of residents' identification with their locality and their general sense of attachment to place. The more people identify with their locality and patronise

Mary P. Corcoran is in the Department of Sociology and National Institute for Regional and Spatial Analysis (NIRSA), National University of Ireland Maynooth, Maynooth, Co. Kildare, Ireland. E-mail: mary.corcoran@nuim.ie. 
local facilities, the more likely the locality is to develop a reputation as a 'good place to live', thereby confirming the prescience of residents' locational choices. The ways suburban residents identify with the locality and make use of it determine in a fairly direct way the social relationships that will develop there. Gans (1968), for example, found that suburbanites develop a sense of community in terms of loyalty towards the place and identification with the local organisations and sports teams. Similarly, Pahl's exploration of the rural-urban continuum in Hertfordshire, England, in the 1960s revealed that the professional middle class who chose to live in commuter villages did not do so simply because of the physical surroundings, but also "on account of a distinctive pattern of social relationships, which they associate[d] with a village" (Pahl, 1968, p. 274).

The aim of this paper is to examine the ways in which contemporary suburbanites perceive and relate to the places where they live. More specifically, I am interested in the mechanisms through which people construct a sense of place attachment in new suburban communities. I argue that suburbanites make sense of their environment by drawing on notions that culture makes available to them. Images of rurality, memories of rural childhoods, pastoral idealisations and so on are tapped in order to express and develop a local 'structure of feeling' (Williams, 1973). This complex of beliefs, values and attitudes can be described as an ideology of pastoralism which enables residents to explain and justify their movement to the suburbs, even when aspects of the suburban experience disappoint.

The paper is based on an empirical investigation of four suburban areas located in the hinterland of the city of Dublin, Ireland, carried out between 2002 and 2005. The New Urban Living Study ${ }^{1}$ involved administering a representative social survey to 800 people across four localities, conducting more than
30 focus group discussions with a range of residents and more than 20 in-depth interviews with key informants. Data analysis reveals the degree to which a sense of place is given expression through an ideology of suburban pastoralism that plays a significant constitutive role in everyday suburban life. Furthermore, the data indicate that, while attachment to place is strong, suburban dwellers nevertheless are cognisant of the problems associated with suburban development. This raises the intriguing question of how it is possible for suburbanites to express an overall attachment to place, while at the same time harbouring significant levels of dissatisfaction with aspects of that place. The answer, I believe, lies in the robust pastoral ideology that animates contemporary suburban settlements. This pastoral ideology masks the disjuncture between the emotional attachment to place and the practical on-going concerns about infrastructural and service deficiencies. As indicated, the ideology is part fuelled by residents' own sense of collective memory and is given expression in a local 'structure of feeling' which may be both real and/or imagined. In the absence of symbolic markers that sustain a pastoral ideology, it is more difficult for people to express feelings of attachment to place. Indeed, residents who express disaffection with place, and whose disaffection is not assuaged by the mediating properties of a pastoral ideology, are more likely to feel unattached and to develop feelings of placelessness.

\section{The Meaning of Place in Suburbia}

The meaning of place has long exercised the minds of geographers, philosophers and sociologists. The German philosopher Heidegger (1978) saw dwelling as the essence of being, offering the individual respite and refuge. Place in this sense of a locus of being, however, is directly threatened by the forces of globalisation that presage mobility, transience and impermanence. Fixity, belongingness and 
attachment are viewed as increasingly anachronistic in our globalised world. Globalisation facilitates the collapsing of barriers of time and space. As the latter recede in significance, social commentators have raised concerns about the emergence of a sense of placelessness in contemporary life. Relph, for example, has argued that the potential for people to develop a sense of place in technologically advanced cultures

has been undermined by the possibility of increased spatial mobility and by a weakening of the symbolic qualities of places (Relph, 1976, p. 66).

In a similar vein, Sennett contends that, as capitalism spreads its tentacles globally into the public space of the city

attachment and engagement with specific places is dispelled ... and the accumulation of shared history, and of collective memory, diminishes (Sennett, 2000).

Others have advanced the notion that society and economy are no longer organised around local relations. As a result, identity formation may be more likely to take place through networks generated by the individual that are extralocal and may extend to include 'virtual communities' (Turkle, 1999; Wellman and Hampton, 1999). Simonsen, for example, suggests that

It is meaningless in modern urban contexts to talk about communities in the sense of selfsufficient social units (Simonsen, 1997, p. 171).

According to Cuba and Hummon (1993, p. 114), as local communities have been subsumed by the larger society, "collective sentiments and personal attachment to locality have weakened".

Yet, it is also argued that, precisely because of the homogenising and deterritorialising effects of globalisation, we need now more than ever a notion of 'place' as stable, secure and unique. Some analysts have suggested that place has become more important as an identity marker for people in an increasingly globalised and speeded-up world. Tovey, for instance, has suggested that

uneven spatial development in late capitalism heightens the significance of location as a source of identity and as a basis for collective mobilisation (Tovey, 2002, p. 182).

Vaiou and Lykogianni (2006, p. 738) contend that increasingly concepts such as sense of place and locality have been utilised to designate a counterbalance to the dislocation, fragmentation and disorientation so often associated with contemporary life. Similarly, Gieryn contends that

in spite of the jet, the 'net and the fast food outlet, place persists as a constituent element of social life and historical change (Gieryn, 2000, p. 463).

Significantly, policy debates at national and European levels remain underlain by the

assumption that the local remains an important arena in the shaping of everyday life, social identity and in maintaining wider processes of social cohesion (Kennett and Forrest, 2006, p. 714).

From this perspective, place is recognised as an empirical mediator between individuals and institutions (Borer, 2006, p. 174).

Yet where are the places that mediate between individuals and institutions? In advanced industrial societies, a growing majority of the population live in suburbs, yet a perusal of the literature on suburbia reveals a systematic denial of their place value. Rather, suburbs are widely condemned for their apparent placelessness. As journalist Lucy Ward has observed wryly

Suburbs are the place we love to ridicule-the mock Tudor home of the Bisto family where Tupperware is king and Shake n' Vac is the drug of choice (The Guardian, 20 April 2004). 


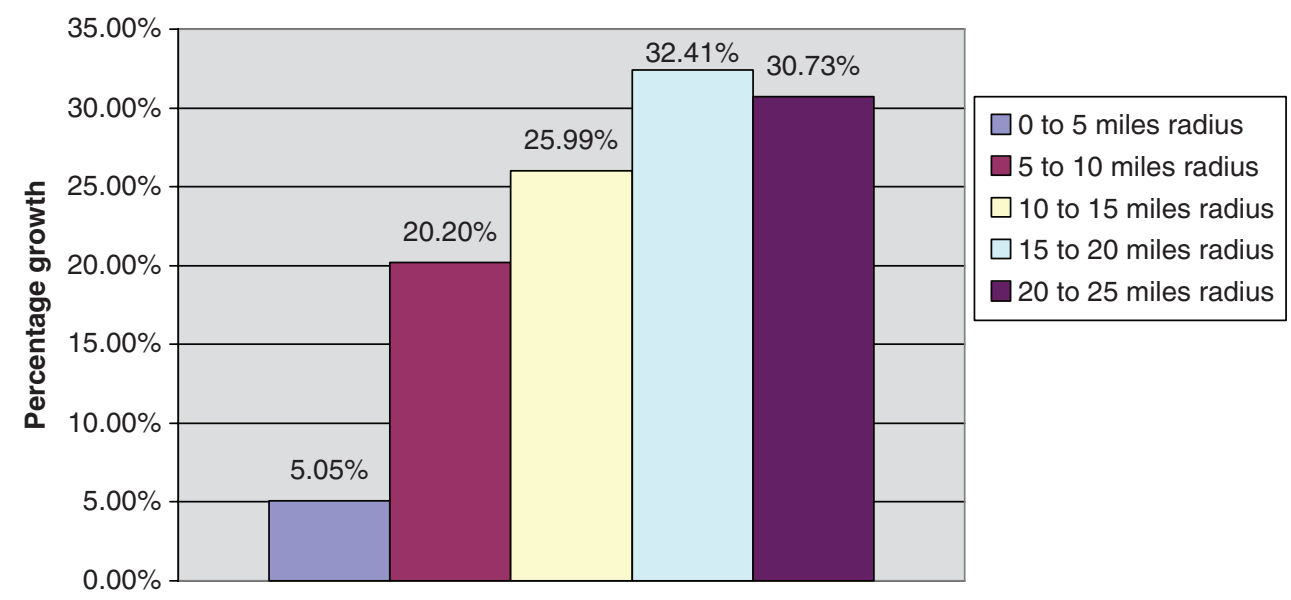

Figure 1. Percentage growth of the Dublin population according to distance from city centre, 1991-2002.

Source: NIRSA. Based on small area population statistics from the Census of Population 2002 and Ordnance Survey Ireland ED (Electoral Division) boundaries.

Notes: Distance buffers were created around a point in the centre of Dublin (approximately the location of $\mathrm{O}^{\prime}$ Connell Bridge) at intervals of 5, 10, 15, 20 and 25 miles. This distance is along straight lines (as the crow flies). Population data for the EDs whose centroids lie within the buffers were summed to provide figures showing the approximate population within these distances from Dublin city in 1991 and 2002.

A negative view of the suburbs suffuses the sociological literature and the public imagination. The suburbs are frequently represented as non-places of homogeneity and uniformity, of stifling conformity, of social atomisation and isolation, of heightened domesticity and a withdrawal from public life. One needs look no further than the novel for evidence of this general disdain. Richard Yates' classic work, Revolutionary Road, (now a major Hollywood film) first appeared in 1961 to critical acclaim. It chronicled the lives of a beautiful but desperate young couple whose dreams are crushed under the weight of suburban life. More recently, Rachel Cusk, in Arlington Park (2006), has tackled the same theme of simmering suburban despair painting a dystopian image of middle-class suburbia in contemporary Britain.

The pervasiveness of that stereotype led to the conceptualisation of the New Urban Living study which sought to document and analyse everyday social and civic life in four different suburbs in and around the city of Dublin. The greater Dublin conurbation has now reached the 1.5 million mark. Over the past 15 years, most urban growth has taken place not at the core of the city, but on its periphery, with large tracts of suburban housing colonising the countryside. As Figure 1 clearly illustrates, Dublin has been characterised by peripheral urban development since the early 1990s. While the urban core grew only minimally between 1991 and 2002, the city expanded into the hinterland creating new suburban neighbourhoods. The further one travels from the city centre, the more marked this suburban growth becomes.

The analysis of Dublin's recent suburban experience provides a worthwhile case study in its own terms, but also in terms of contributing to the general social science scholarship on suburbs. The choice of suburbs around the city of Dublin is particularly apposite. Dublin is a major European 
city and Ireland's primary economic, social and political relationships now take place within a European Union framework. Notwithstanding that fact, Ireland, for historical, economic and cultural reasons, is very much open to Anglo-American influence. Hence, the city's suburban frontier is likely to be influenced by international trends emanating from Europe and America, and also by the nation's own indigenous relationship to the land (see Quilley, 2002). Indeed, the spatial form of Irish suburban development over the past two decades owes much to the property boom that engulfed the country during Ireland's 'Celtic Tiger' years. The study of the contemporary suburbs illuminates a set of processes that provide insight into the ways in which suburbs more generally develop, consolidate across time and become the object of affection or disaffection amongst those who live there.

The research strategy adopted was based on a comparative analysis of four different suburbs at contrasting stages of development and located at different points in relation to the metropolitan core (see Table 1). Ratoath, Co. Meath, was a very small village until the late 1980s when its population began to multiply dramatically. Ratoath became particularly attractive as a destination for Dubliners seeking to move further out from the city. Leixlip, Co. Kildare, is an established suburb where growth has stabilised. The locus of intense growth in the late 1970s, growth continued at a far slower pace in the 1980s and slowed considerably in the 1990s. The new electoral division of Lucan-Esker, sited to the south of Lucan village in South Dublin county, has grown at a staggering pace in recent years, in a locality which was already heavily suburbanised. Finally, Mullingar, an established provincial town in Co. Westmeath, became a growth pole during the past decade, attracting commuters from Dublin but also enabling many people born and bred in the town to make their homes there.

Table 1. Population change in four Dublin hinterland suburbs, 1996-2006

\begin{tabular}{|c|c|c|c|c|c|c|}
\hline \multirow[b]{2}{*}{ Study site } & \multirow[b]{2}{*}{ Suburb type } & \multirow{2}{*}{$\begin{array}{l}\text { Distance from } \\
\text { Dublin city } \\
\text { centre }\end{array}$} & \multicolumn{3}{|c|}{ Population } & \multirow{2}{*}{$\begin{array}{c}\text { Percentage change } \\
\text { 1996-2006 }\end{array}$} \\
\hline & & & 1996 & 2002 & 2006 & \\
\hline $\begin{array}{l}\text { Ratoath } \\
\text { Co. Meath }\end{array}$ & $\begin{array}{l}\text { Rural village } \\
\text { that experienced } \\
\text { rapid growth since } \\
1996\end{array}$ & 18 miles & 3064 & 5581 & 8805 & +187 \\
\hline $\begin{array}{l}\text { Leixlip } \\
\text { Co. Kildare }\end{array}$ & $\begin{array}{l}\text { Mature suburb } \\
\text { that grew rapidly } \\
\text { in the } 1980 \text { s but } \\
\text { has stabilised since } \\
\text { then }\end{array}$ & 9 miles & 13585 & 15154 & 14833 & +9 \\
\hline $\begin{array}{l}\text { Lucan-Esker } \\
\text { Co. Dublin }\end{array}$ & $\begin{array}{l}\text { Suburb that has } \\
\text { continued to grow } \\
\text { since its earlier } \\
\text { development in } \\
\text { the 1980s }\end{array}$ & 7 miles & 7451 & 20807 & 25823 & +246 \\
\hline $\begin{array}{l}\text { Mullingar } \\
\text { Co. Westmeath }\end{array}$ & $\begin{array}{l}\text { Suburban develop- } \\
\text { ment on perimeter } \\
\text { of provincial } \\
\text { town }\end{array}$ & 50 miles & 4747 & 7012 & 9652 & +103 \\
\hline
\end{tabular}

Source: Central statistics office. 
The New Urban Living Study focused on three interrelated domains of everyday life: sense of place and social belonging; family life, including household work strategies and networks of social support in the community; and local participation in social and civic life. (The present paper focuses only on the issue of place attachment.) The four case study localities are drawn upon to illustrate the meaning of place in contemporary suburbia and, in particular, to explain how notions of place are mediated through an ideology of suburban pastoralism.

\section{Place and Place Attachment}

Our unique, human responses to places and the associations they carry in terms of memories and fantasies are at the roots of attachment. Indeed, they are directly related to the process of developing self-identity (Childress, 1996, p. 341). In other words, concrete everyday practices give rise to a cultural mediation or 'structure of feeling' (Williams, 1973). Consequently, one place as opposed to any other may become the object of identity for the subject (Agnew, 1993, p. 263). Riley counsels that attachment to landscape is complex, based as it is on

a set of threads woven through one's life. Childhood's landscapes, and later attachments to landscapes, are not only sources of satisfaction in themselves but the stuff of an ever-changing interior drama within the human psyche (Riley, 1992, p. 18).

Place, then, denotes an environment that may be 'experienced' (even if only in the imagination) rather than rationally examined or economically valued, an environment seen as a personally relevant whole rather than as a distant set of divisible or abstract components (Childress, 1996, p. 340). Places are not only built and imposed upon the landscape, "they are also interpreted, narrated, perceived, felt, understood, and imagined" (Soja, 1996; quoted in Gieryn, 2000, p. 465). Places are not simply physical forms and backdrops, nor are they simply a context for social interaction. They are also the repositories of imagery and projections, traditions and memories. Places, as Relph has suggested, are not reducible to simple locations but constitute "centres of existential experience” (Relph, 1976, p. 88). Hence, in thinking about place, we must consider not only their materiality in space, but also their meaningfulness as places and as sites of social interaction.

Places-such as villages, small towns and, indeed, greenfield sites-that undergo suburbanisation are frequently assumed to lose their distinctiveness, their unique sense of place. As noted earlier, suburbanisation is frequently equated with homogenisation. When country fields are redeveloped as up-market suburban outposts, when rural villages hum to the sound of juggernauts trundling through, when provincial towns become in the words of the locals "a dormitory suburb of Dublin", the locally rooted sense of place is often thought to become destabilised. People fear that the place is losing something of its character, popular memory and tradition. And yet, the majority of residents who participated in the New Urban Living study across the four different localities feel attached to the place where they live: 53 per cent of Lucan-Esker respondents indicated such an attachment, but the figure rose to 64 per cent in Mullingar, 72 per cent in Leixlip and 79 per cent in Ratoath. Thus, suburban living seems not to preclude the persistence of local attachments based on nurturing social relations and identification with place.

It is necessary, however, to sound a note of caution. Feelings of attachment to place, while strong, are also somewhat precarious. Places are not static but dynamic and are likely to change and evolve-for the better or for the worse-over time. This is particularly true during periods of rapid suburbanisation when villages and small towns undergo major development. The original signifiers that 
proved attractive to prospective residents are somewhat undermined by overdevelopment and/or the threat of development, and this renders attachment to place more fragile.

Attachment to place is frequently bound up with ideas about the nature of place as construed through signifiers in the built and natural environments, and mediated through particular imagery, memory and tradition. Bridger points out that heritage narratives are of particular importance in this respect, because they provide a version of a community's history that forms what he calls a "constitutive rhetoric" (Bridger, 1996, p. 353). Thus, collective representations and rhetoric provide residents with the tools through which they can interpret and make sense of their environments. Sentiment plays an important role in developing an attachment to place. This sentimental attachment to place may be based both on symbolic representation or 'markers' and also on myths, narratives and collective memories. These various place markers are frequently overlain on each other and feed into a pastoral ideology of suburban place.

\section{Seeking the Pastoral Suburb}

Suburbs owe their origin to the anti-urbanism of the 19th century. For first-generation suburbanites, the suburb "represented an escape from the filth, noise, and debauchery of the 19th century industrial city" (Palen, 1994, p. 68). For suburbanites, Palen argues, rural images and supposed rural values continue to hold popular appeal. The portrayal of the rural as idyllic is an attempt to construct space as pure and uncontaminated by unwanted others (Sibley, 1995). It leads to the aestheticisation of the countryside, even as the latter is colonised by swaths of suburban housing and becomes in essence the object of the urban. According to Newby in his exploration of the impact of urbanisation in rural East Anglia, the urban middle-class exodus to the countryside is predicated on "culturally induced assumptions about the wholesome authenticity of rural life" (Newby, 1979, p. 482). Once ensconced in the countryside, the locally oriented transplanted urbanites become "the self appointed guardians of tradition and rusticity as they define it" (Pahl, 1968 , p. 274). Bell's study of an ex-urban community in Hampshire found that the village and the pastoral backdrop of the surrounding countryside constituted the dominant interpretive frame for local residents. The countryside became a "moral rock" (Bell, 1994 , p. 8) against which other forms of living were measured. Authenticity was equated with 'countryness', which helped to feed into a strong anti-urban ideology. Similarly, in the US, pastoralism emerged as an important alternative to urbanism, juxtaposing an idealised version of rural living against the moral turpitude of city life. Rowe (1991) has described this hankering for a rural idyll as an ideology of pastoralism that is seen to inform the growth and development of many of the early suburbs in the US, and particularly the garden suburbs. According to Rowe

Pastoralism continues to serve as a critical lens through which to mark human progress and as an optimistic source for dealing with threats encroaching from either a natural or urban wilderness (Rowe, 1991, p. 226).

Thus, it offers a middle landscape mediating between a natural and untamed rurality and the imprint of civilisation evident in urban and suburban development.

The rural ideal has a particular resonance in Ireland. Ireland did not experience a large industrial revolution on a par with most of Europe and the US in the 19th century, and so remained a largely agrarian society well into the 20th century. Furthermore, antiurbanism constituted a major element of the anti-colonial strategy pursued by politicians, artists and writers in the lead-up to Irish independence and its aftermath (Horgan, 2004, p. 38). At the core of the Irish nation-building 
project, Horgan argues, was the conflation of rurality and nationalism, standing opposed to the city and city life. Kiberd contends that, at the turn of the 20th century as the nationalist movement gained momentum, rural Ireland was increasingly equated with real Ireland. This became the model for subsequent Irish politics. Conveniently, the mythologising of rural Ireland served to obscure the very real rural class divisions that emerged in the wake of the Land Acts of the 1880s (Kiberd, 1995, p. 482). Ironically, the pastoralism of revolutionary leaders such as Michael Collins was rooted in the English Romantic movement of Wordsworth and the Lake Poets. Sentimental attachment to the rural, then, is deeply rooted in Ireland's political and cultural traditions and serves as a resource for contemporary suburbanites to draw upon in constructing their own version of the pastoral.

The demographic shift of population to the suburbs reflects a movement of people who themselves (or whose parents) came from rural areas. Indeed, Irish people do not generally consider themselves to be urbanites (McManus, 2003, p. 31). While the suburban expansion of the late 20th and early 21 st centuries in Ireland is in part explicable by the lure of the rural idyll, the 'unspoilt' landscape of the countryside, it is also conditioned by the widespread conversion of formerly agricultural land into suburban developments to meet the needs of a mobile Irish middle class (Collier, 2004).

While Rowe was concerned with pastoralism per se, I argue that, in new suburban communities, a variant of that ideology emergessuburban pastoralism - that coheres mainly around the ideal of rural village life, albeit that the village is located within a wider urban grid. According to Bonner, the very act of expressing a preference for 'rural living' on the part of urbanites, and acting on that by moving outwards from the city, suggests that 'the rural' by definition, can no longer exist (Bonner, 1997, p. 53). Nevertheless, nature and rurality often conceived of in terms of pastoral imagery-open fields, grazing animals, plentiful greenery-operate as ideological magnets for prospective suburbanites. The place of nature in the suburb and the significance attached to it by suburban dwellers are complex and may vary across localities because nature

both influences and takes on different reality depending on how, as a continuous matter, it lashes up with the other aspects of the local milieu (Molotch et al., 2000, p. 794).

Environmental backdrops, both natural and constructed, come to be inscribed in our place consciousness and offer important markers of local identity. In the case study suburbs reported on here, the rural retains an important symbolic and ideological dimension for residents. In the case of Ratoath, Co. Meath, and Leixlip, Co. Kildare, in particular, residents look to pastoral signifiers to define their sense of place. In both cases, residents identified a set of 'pastoral images' that they felt characterised their place. The significance of nature is much less pertinent in Lucan-Esker, Co. Dublin, where the preexisting pastoral landscape is perceived to have been largely destroyed through overdevelopment. In Mullingar, Co. Westmeath, the context is somewhat different from the other three localities. As a provincial town that is now ringed by suburban housing estates, Mullingar does not fit the 'ideal type' of the sleepy village set in rolling countryside. It does, though, retain a rural character by virtue of its midlands location and status as a provincial town. Crucially, the majority of people living in new suburban housing estates in Mullingar have lived in the town all their lives. Their historical roots in the setting help to secure both the memories and traditions of the place, in the absence of pastoral signifiers.

In Ratoath, the character of the place is frequently described in terms of the physical 
landscape, whereas in Leixlip it is primarily seen to inhere in the quality of community life, but both are linked to an idealisation of rural life. Ratoath's greenery-the hedges, fields and trees - act as important signifiers of the countryside and rurality for respondents, both young and old. When asked in the survey questionnaire to define Ratoath as a place, respondents referred mainly to its village atmosphere ( 52 per cent) and 'country feel' (39 per cent). They also referred to the friendliness (32 per cent) and community sense (21 per cent) of the place. One survey respondent rather poignantly captured the quality of the rural that he sought in Ratoath, although he concedes it is somewhat deficient in this respect

I know it's not country but it's as near to the country as one can get. It's homely. But for Mass on Sunday I go back to the church in Dunboyne [nearby village], I like the feel of it (respondent 1251).

Rurality was associated with a positive experience of parenting for Ratoath residents. Parents remarked on what they characterised as 'the country attitude' in the local school. This denoted a more personal, friendly approach to teaching and parental contact. In their experience, this personal touch was largely missing from Dublin schools. A participant in the 'mother and toddler' group remarked that she liked the "ruralness of the place" especially the greenfields and the fact that it was "not all concrete". Such comments suggest that it is the aesthetic of rurality to which people are attached, rather than the countryside itself. The reality is that the countryside around Ratoath is under threat from development. The population has increased dramatically between the censuses of 1996 and 2006 (see Table 1) with several new housing estates coming on stream in recent years. In this context, the idea of Ratoath as a pastoral retreat configured around a small rural village is directly contradicted by the physical reality of contiguous suburban estates extending along all approach roads out into the surrounding countryside. The pastoral ideology must, therefore, be expressed in increasingly symbolic ways.

Pastoral ideology is also reproduced by children growing up in the locality. In describing the place where they live, local children tended to evaluate positively the rural and negatively the urban, reflecting an anti-urbanism that is inscribed in Irish culture. Children in focus groups observed that, despite all the development and the fact that a lot of people do not know each other, Ratoath has not lost "its country look". Respondents were adamant that they did not want Ratoath 'to be Dublin' and expressed concerns that Ratoath could be swallowed in a greater Dublin conurbation

Ratoath is growing nearly too fast. It's a friendly town with a huge population. There used to be greenfields around Ratoath, not any more it's just filled up with estates. I would like to see the building of estates stop before we join up with other towns. Take for example Malahide, it used to be like Ratoath except much bigger but estates and buildings flowed in and now Malahide and a nearby town called Swords are joined together. I don't want to see that happen to Ratoath (sixth standard pupil, Ratoath).

The aesthetic of rurality does not define Leixlip residents' experience of place to the same extent. While village atmosphere (18 per cent) appeared as one of the features that defined the place for our survey respondents, 'country feel' did not emerge as a significant theme. This is perhaps not surprising given that Leixlip has a long history as a small urban place, with an established main street and small business community. Instead, the dominant themes were friendliness (28 per cent), quietness (16 per cent) and community sense (14 per cent), all factors associated with small town living. Bridger (1996) suggests that the motifs of history and heritage may be extremely salient in residents' self-definition. Indeed, the history 
and heritage of the place (16 per cent) emerged as a significant theme in Leixlip, indicating that the visual presence of heritage in the built environment provides an alternative pastoral backdrop to which people may become attached. According to one of our key informants, Leixlip has a kind of 'schizoid identity'

This is because of its proximity to Dublin on the one hand, and its character as a sleepy rural village on the other. There are a number of natural boundaries in the area that reinforce the rural village character: the canal, two rivers, a lake and picnic area.

Many respondents in Leixlip and Ratoath saw their suburbs as a gateway from the city to the countryside. This is suggestive of Rowe's (1991) idea of a 'middle landscape'-a place that permits access to nature but also is accessible to the facilities and infrastructures associated with dense settlements

I've lived in Co. Meath all my life. I believe I have the best of both worlds. A semi-rural location with the city of Dublin on my doorstep (respondent 1182).

Putting it in more literary terms, the middle landscape of Leixlip was characterised by another respondent in terms of two iconic Irish writers, both representing different traditions

Leixlip is a cross between J. B. Keane and Brendan Behan, a mix of the two, country and Dublin, rural and urban (respondent 2007).

Whereas for Ratoath residents the presence of greenfields 'proves' that it is in the country, for Leixlip residents the 'country attitude' inheres in the quality of local relationships and the nature of local organisations that have evolved over time. Indeed, one key informant suggested that the sustainability of a suburb such as Leixlip was largely predicated on the rural ethos of the suburbanising population and their willingness to work together to achieve common aims
Huge numbers of people were cleared out of rural Ireland and dumped on the outskirts of Dublin. What saved those communities was that people were rural-people were used to having to do for themselves. ... In Leixlip, people's backgrounds were rural, people would get out and mow the public greens, they would look after the maintenance, taking pleasure in hacking down a bush. The residents' association reflected this rural and small town ethos of mucking in and doing things.

Here, we are presented with an idealised notion of a stoic peasantry which would not be out of place in the Revivalist writings of late 19th century Ireland, to which Kiberd (1995) and Horgan (2004) allude. The statement is implicitly anti-urban: it is the rural dwellers who have the capacity to domesticate the landscape for resident suburbanites.

Another informant went on to elaborate how the character of the place inheres not just in its physical location in space, but also in the social infrastructure that provides people with a basis for attachment

While it is in Dublin, it still has the quality of a provincial town, it has retained the things you remember from a provincial town. It has its own town council, musical society and drama group. It's bordering on the country, and it's mainly country people. There is an ordinariness about it, and a pride of place.

Interestingly, when asked what they liked most about living in Leixlip, many more people mentioned its closeness to Dublin (27 per cent) than its friendliness ( 9 per cent), whereas in Ratoath people mentioned the countryside (28 per cent) about as often as closeness to Dublin (22 per cent). The evidence seems to indicate that, in line with Bonner's (1997) argument, Ratoath residents-largely uppermiddle-class people, most of whom are at a relatively early stage of family formationhad actively chosen the aesthetic of rurality that this 'new' suburb appeared to provide, at least partly on the grounds that it offered 
the opportunity for a better family life in a country setting. In Leixlip, on the other hand, with its longer history as a suburb, its somewhat older age profile and greater diversity in family and occupational structure, residents perceived the place where they live to be pleasantly unexceptional. Nevertheless, in both instances, local residents perceive the quality of life enjoyed in the community to be at least in part derived from the rural ethos that underpins the locality. This rural ethos is given active expression in a pastoral ideology that frames both residents' everyday understandings and interpretations of place. It appears that, in the suburbs, the process of collective representation through symbolic markers that help with personal identification in the context of the city (Borer, 2006) is also heavily relied upon for helping to delineate an inclusive suburban community. The images and representations of a place like Ratoath (relying heavily on nature) and Leixlip (relying on heritage and community) help to create common background referents for suburban dwellers.

\section{The Limits to Pastoralism}

The picture in Mullingar and Lucan-Esker, where we recorded somewhat lower levels of place attachment, is somewhat more nuanced. When thinking about Mullingar as a place to live, 48 per cent of respondents in the new housing estates cited its character as a provincial town, while almost the same proportion (43 per cent) identified it as a modernising town. The town's rural aspect was alluded to by 37 per cent of respondents. Mullingar is somewhat different from the other three case studies in that the suburban growth has not occurred in the first instance around a sleepy rural village, but on the perimeter of a well-established town. The particular character of place for Mullingar residents is defined more pragmatically in terms of its practical convenience and less in terms of the access offered to a pastoral or heritage backdrop. Indeed, one local observed that the environmental backdrop to Mullingar was generally unremarkable

The locality is flat with little character-with no sea or mountains nearby. It is now a dormitory town of Dublin.

Mullingar is liked for its centrality-it is accessible by road to the cities of Galway and Dublin, and is viewed by residents as a place literally on the way to somewhere else. Yet crucially, most of the population has a shared collective memory of Mullingar based on length of residence and this feeds into a positive disposition towards place. As Borer (2006, p. 186) remarks, "social, public, collective memories are stored and transmitted in and through places". Such collective memories and adherence to a shared tradition play a similar role for Mullingar residents as rural signifiers do for the residents of Ratoath, and the heritage and community ethos does for suburbanites in Leixlip. Some local residents in Mullingar, for instance, talked about the rivalry that exists between the two premier towns in the County of Westmeath, Athlone and Mullingar. There is a palpable sense of grievance arising from the fact that Athlone is seen to have benefited to a much greater degree than Mullingar from the economic spin-off of the 'Celtic Tiger'. This is noteworthy because, even though expressed as a grievance, this indicates that local residents have a particular allegiance to Mullingar - it matters to them that Mullingar has been 'passed over' for investment and targeted development.

As is the case in Mullingar, the features that people called to mind in Lucan-Esker when thinking about Lucan as a place were somewhat contradictory. Thirty-five per cent of respondents mentioned its 'built-up' character, while 34 per cent also identified the place with 'quietness'. When asked what they 
most liked about Lucan, survey respondents mentioned its convenience and closeness to Dublin more frequently than any features that inhere in the place itself. This resonates with the views of those Mullingar residents who saw the convenience of their town's strategic location between Galway and Dublin. In the focus group discussions conducted in Mullingar and Lucan-Esker, participants had greater difficulty than their counterparts in Leixlip and Ratoath in identifying key features of the physical and social environment that they saw as defining their place. The absence of clear environmental signifiers that give definition to place, may explain, in some part, the lower levels of place attachment recorded in both Mullingar and Lucan-Esker, and the tendency, particularly in the latter, for some respondents to express a sense of placelessness. Symbolic markers embedded in myths, traditions, narratives and collective memories and frequently expressed in a pastoral ideology are important mechanisms for place-making and inculcating a sense of place. When such symbolic markers are not present or have been subject to undue strain, places become more susceptible to placelessness. They cease to act as "sources of security and identity" for people (Relph, 1976, p. 6).

Part of the problem in Lucan-Esker is the disconnection between the original village and the surrounding sprawl of suburban estates. Spatially, Lucan has expanded far beyond the boundaries of the village and any connection between the village and the new estates is extremely tenuous. Many of the new developments are cut off from the village by a major highway and are sited at a considerable distance from the village shops and amenities. There are no local buses operating in the area to make access to the village easier, especially for those without cars. The village, then, does not feature as an anchor providing the locality with a sense of place as it does in both Leixlip and Ratoath. The latter boast an accessible 'Main Street' that acts as an important point of orientation for locals and at least in theory can capture "the essence of the romanticism of the small town" (Francaviglia, 1996, p. 159). In the case of the new estates that have developed on the outskirts of Lucan village, there are only traces of the kind of pastoralism that was prevalent in the other localities. Indeed, there is a poignant recognition that Lucan's 'rural' identity is now a thing of the past

It's fairly historical, farms are at the heart of it, or at least were at one time (respondent 3080).

The estate is just 'new', the village has lots of history and charm but not in its surrounding areas (respondent 3091).

It has a nice picturesque village feel in the village area but the estates are just a concrete jungle (respondent 3146).

Since the newer estates are not configured closely around the village, the romantic patina of the 'Main Street' does not extend to them. The character of the village fails to animate these new developments, because their orientation is much less spatially focused on the village as nucleus than in either Ratoath or Leixlip. In other words, Lucan-Esker really does suffer the deleterious effects of suburban sprawl

It's gone beyond a village now, it's primarily houses, too much building, little of the greenfields left, mass population (respondent 3096).

In this instance, the respondent's reference to the locality is purely in terms of its built form. The locality is talked about as a location rather than as a locale with a particular 'structure of feeling'. The absence of symbolic markers of place, of narratives and collective memories is telling. According to Relph (1976), the weakening of the symbolic qualities of places is a function of a highly technocratic and spatially mobile economic conjuncture. For many of the residents of Lucan-Esker, a sprawling outgrowth of a village that has been overwhelmed by suburban development, 
sense of place is much less in evidence than in the other case studies.

Respondents clearly distinguished between the older suburban estates in Lucan (configured around the village) and the newer area of Lucan-Esker, which has developed beyond the village and to the east of the N4 highway

My area-these estates are new and suburban-it lacks a community as opposed to 'old' Lucan village which is very different (respondent 3089).

There are two parts to Lucan: the old village part has tighter community. In the estates, people are more distant, if you like privacy then the estates are a good place to be (respondent 3223).

The kind of unfettered outward expansion that characterises Lucan-Esker, a suburb that began growing in the 1970s and has continued to expand apace, appears to have a quite negative impact on sense of place attachment. In effect, a spatial rupture has occurred. In the other localities, the village (Leixlip and Ratoath) or the town (Mullingar) remains the focal point of orientation for the local population. Suburban life radiates outward from the Main Street. In Lucan, the village can no longer act as a point of local orientation or cohesion because the links with outlying estates have become too weak. Place attachment is therefore seriously undermined.

In his analysis of the middle landscape of suburbia, Rowe points out that

continuity with the past, particularly a simple rural existence ... can ameliorate the course of rapid growth and vast social change (Rowe, 1991, p. 239).

It is clear from the New Urban Living study that a pastoral ideology frequently expressed through an adherence to aesthetised rurality, tradition and collective memory provides the means for suburban residents to develop a sense of place attachment. The pastoralism which animates suburbanites has a basis in material reality - the presence or absence of a village or rural landscape, or heritage backdrop. These matter to people in constructing their sense of place. Crucially, the pastoral ideology remains salient to residents in feeling and expressing a place attachment, even as they recognise the many ways in which their material place has been undermined through overdevelopment, poor planning and infrastructural deficits. In this sense, the pastoral ideology serves to justify and legitimate the move to the suburbs, and to paper over the cracks where the material reality diverges from the suburban ideal type.

\section{Placelessness}

While so far we have focused on the positive aspects of generating attachment to place, this does not convey the full picture of life in the new suburbs. A substantial number of respondents feel either no attachment to place, or actively feel detached or even alienated from place. Lucan-Esker has the highest proportion of disaffected residents. Whereas Lucan, 30 years ago, was a suburb not dissimilar to Leixlip, both areas have moved along different trajectories since then. The growth and development of Leixlip had largely tapered off by the 1990s, whereas in Lucan, development continues apace. The features that people identified when thinking about Lucan as a place to live appear somewhat contradictory. The most commonly cited features included its 'built-up character' (35 per cent) and its 'quietness' (34 per cent). People may be responding to two different levels of Lucan here. On the one hand, Lucan as an entity is an agglomeration of estates bisected by a series of national and secondary roads and highways. This gives it its 'built up' character. On the other hand, most people live in estates and these estates form the natural boundaries of each individual's own mental map of his or her immediate neighbourhood. Life on the 
estates may be pretty quiet and unexceptional. Indeed, the very quietness of the estates can make them more alienating for some residents, because there is little opportunity to foment communality and solidarity. One resident, for example, remarked that

Someone tried to break in during the day while I was in the house. What makes it worse is that there was nobody on the estate. A lot of the time, people are not there (mother and toddler group member).

Considerably fewer people in Lucan-Esker felt attached to the place than in the other three localities investigated. The terms used by respondents to describe Lucan give some clue to their feeling that it lacks character, or a sense of place. Whereas the notion of Leixlip as a 'middle landscape' was perceived positively - as retaining access to the city but enjoying the amenities of the countryLucan-Esker's in-between status was viewed more negatively

It's near to the city and the country, it's a no man's land, it's impersonal and quiet (respondent 3076).

It's a house that could be anywhere, my wife feels a connection here, I have no sense of Lucan at all (respondent 3263).

It's an ant hive- - house after house, people need houses but not on top of you (respondent 3277).

There is a palpable sense that development has produced serial homogeneity and uniformity in the landscape and that this impacts negatively on everyday quality of life. This is an observation made frequently by residents of Lucan-Esker but also (although to a lesser extent) by disaffected residents in Leixlip

It's a box to live in. There's definitely no community here (respondent 2161).

You hardly see your neighbours' faces from one day to the next. No one has time anymore.
Paving in driveways, no time for gardens. It has lost its country feel (Respondent 2166).

In Lucan-Esker, and to a lesser extent in Ratoath and Leixlip, concerns were expressed about the decline or disappearance of village life and community. Here, some residents expressed the 'lost' thesis that the suburban way of life is a largely privatised one and that increasingly suburbia is devoid of any meaningful sense of place (Wellman, 1979). The heart has been torn out of the community through unfettered development and the relocation of the shopping function away from the main street to large, out-of-town shopping centres and malls. Life in suburbia is experienced by these residents as anomic and alienating, and they are quick to contrast the suburban lifestyle with an ideal-type version of community

It's [Lucan] losing its character, it's impersonal, cold. People don't talk to each other (respondent 3076).

It's [Lucan] a dormitory town, lots of rental houses, big turnover of homes, anonymous community (respondent 3045).

It [Ratoath] was a lovely country village, it has become a bit of a monster (respondent 1003).

There were very few houses at first [Ratoath]. Over latter years, thousands of houses [were built]. We used to know everyone but with the present population you might as well be living in O'Connell Street (respondent 1247).

It's [Leixlip] more or less a large encampment, not a village. When we came here you could buy thread or a screw. The village is now gone. We go to Maynooth or Lucan to shop. No sense of town or village. No heart. Many old residents have left (respondent 2291).

The blame for this state of affairs is laid squarely at the door of the planners

There are two distinct styles in Lucan: one, Old Lucan which is a village style. Two, the modern 
urban sprawl with no community heart. The type of planning individual [who planned Lucan] excludes a heart (respondent 3147).

It's [Ratoath] not the kind of place that encourages a sense of belonging. Urban-type sprawl. No play facilities for children. No central shopping district per se. Nice walks but too dangerous. Even to have a coffee you have to go to Blanchardstown (respondent 1022).

The relationship between an individual and his or her locale reflects the (often underestimated) significance attached to place in everyday life. For residents in suburbia, the project of generating 'existential significance' is deeply imbued with a sense of place. While place attachment involves positively experienced bonds, these bonds are tested in the face of changes in the people, processes or places (Brown and Douglas, 1992, p. 284). Estates created on the edge of established suburban settlements are not so easily integrated into the locality. Indeed, those who live there may feel actively disconnected. For these residents, there is a palpable sense of placelessness expressed in terms of feelings of entrapment and disconnection. In essence, these residents are disaffiliated and likely to feel little loyalty to the locality. Hence, they are the least likely to become socially embedded in the suburbs over time.

\section{Conclusion}

This paper takes as its point of departure the idea that place matters and that, despite all of the changes that have taken place in everyday life, people still seek an attachment to the local, and, to varying degrees, find solace in such an attachment. There is considerable evidence from the New Urban Living study that local attachments based on identification with place and personal social relations persist, bearing out the argument that much of human experience does not transcend but rather continues to be bound by time and space constraints. Hummon (1990) identifies three sets of imagery volunteered by suburbanites that are salient to understanding the appeal of the suburbs. First, suburbs are 'clean, quiet, natural' places with an easy-going ambience. While they may not be country, they provide easier access to nature than the city. Secondly, suburbs are places of domesticity where the focus is on home, family life and children. As one of the New Urban Living respondents commented, the suburbs are "God's golden acre for children". They offer the best of both worlds for children in terms of freedom and security; and, finally, suburbs differ from cities in that they are safe-this safety enables other values such as sociability, family and good child-rearing practices.

We find that this ideal-type conception of the suburbs is extremely pertinent to the way in which many Irish suburbanites think about and interpret suburban living. People like places that have a village at their heart, a 'country feel', a sense of connectedness to the past, and that resonate with collective memories. They aspire to raise children within the contours of that 'country feel' which underpins their notions of what a safe, community-oriented, secure environment should be. These beliefs, values and attitudes are largely expressed through a suburban ideology which relies heavily on symbolic markers. In reality, however, the conditions of existence in suburbia frequently fall short of the ideal type. Yet this disjuncture between real and imagined suburbia remains opaque for many residents because of the powerful constitutive role that pastoral ideology plays in the construction of place attachment. The ideology allows for place to be viewed, at least to some extent, in the abstract. It is seen as exhibiting a range of characteristics that may be quite divorced in the suburban imaginary from concrete, practical considerations and from the real, material conditions of everyday suburban life. Hence, residents can be very positive about the place where 
they live and articulate strong feelings of place attachment, while nevertheless articulating a critique of local service and infrastructural deficits. Pastoralism promotes attachment to place and ameliorates the kind of 'landscape amensia' that Duffy associates with suburban landscapes where rapid changes have taken place (Duffy, 2003, p. 25).

For those minority of residents for whom there were no salient signifiers or markers of place, who viewed themselves as confined to 'boxes in the 'burbs', place attachment was much more tenuous. They tended to express high levels of disaffection about the locality and their everyday experience of suburbia was pervaded by a sense of disaffiliation from the locality and the community. Attachment to place helps to embed people in their communities. Placelessness has the opposite effect, disembedding people and rendering them susceptible to anomie and alienation.

It is a bit too glib to conclude that all four suburbs are simply dormitory suburbs of Dublin. They all have tendencies to be so, but their different histories, traditions, infrastructures and community composition make for very different experiences. The New Urban Living study demonstrates that the stereotypical view of suburbs as non-places is both too sweeping and too reductionist. Leixlip, Co. Kildare, comes closest to effecting what Rowe terms

a rural-urban synthesis that ultimately combines and fuses a pastoral perspective and a modern technical orientation (Rowe, 1991, p. 218).

In Lucan-Esker, Co. Dublin, this combination is also pertinent, but the pastoral is considerably more compromised than in Leixlip. Concrete has replaced rural signifiers and a pastoral ideology has much less resonance. Ratoathians in Co. Meath adhere most strongly to a straightforward ideology of pastoralism. They view signifiers of nature and rurality as forming a particularly pleasant and tranquil backdrop, that represents an alternative to urbanism. Once again, unfettered development has resulted in much of this pastoral environment being eroded. Nevertheless, the majority of residents continue to subscribe to a pastoral ideology when describing their place. Village life and the village identity are reified, even as residents live, work and commute within a much wider urbanised grid. While Rowe has argued that continuity with the past can act as a bulwark against social change, this cannot keep the implications of social change in check indefinitely. Continuity with the past (in terms of the natural backdrop, local geography, collective memory and tradition) has become increasingly attenuated over time in Leixlip, Lucan-Esker and Ratoath, resulting in a lack of fit between the imagined suburban place and its material reality.

A strong pastoral ideology informed the decisions of many of the early pioneers who moved to Leixlip. Over time, they have helped to develop a vibrant community that retains a rural ethos through local sports organisations and parish networks. At the same time, Leixlip has good transport links to Dublin and is no longer an outer suburb within the overall Dublin configuration. In Ratoath, the pastoral is also given a special place, but largely grounded in an anti-urban bias. There is a sense in which people in Ratoath are fleeing the problems associated with modern urban life by re-locating on the city's edge close to a rural reality.

The sense of attachment in Mullingar is predicated on the connections that exist between family members and the local nature of those networks. It is likely, however, that over time residents who have originated in Dublin may try to move back closer to the city, while those who hail from Mullingar will deepen their attachment to the locality. Finally, in Lucan-Esker, which falls firmly within the city's urban grid, pastoral and anti-urban ideologies are much less salient. There is some evidence of an orientation 
towards symbolic village life, but estate living rather than village living emerges as a significant motif. Lucan works as a base from which to access the city and other conveniences. It is a place that encourages mobility rather than attachment. Indeed, many of the new estates in Lucan-Esker are deemed as 'first-time-buyer' estates, implying that the population will by definition be transitory. In that sense, it may be much more a harbinger of the future of Ireland's suburbia than Leixlip, Mullingar or Ratoath. If, as I have argued, a sense of place is important for social identity and cohesion, the absence of a sense of place-placelessness in the suburbs-presages higher levels of disaffiliation and anomie in the future.

\section{Note}

1. See M. P. Corcoran, J. Gray and M. Peillon (2010) Suburban Affiliations: Social Relations in the Greater Dublin Area. New York: Syracuse University Press.

\section{References}

Agnew, J. (1993) Representing space: space, scale and culture in social science, in: J. Duncan and D. Ley (Eds) Place, Culture and Representation, pp. 251-271. London: Routledge.

Altman, I. and Low, S. M. (Eds) (1992) Place Attachment. New York: Plenum.

Bell, M. M. (1994) Childerly: Nature and Morality in a Country Village. Chicago, IL: University of Chicago Press.

Bonner, K. (1997) A Great Place to Raise Kids: Interpretation, Science and the Urban-Rural Divide. Quebec: McGill Queen's University Press.

Borer, M. I. (2006) The location of culture: the urban culturalist perspective, City and Community, 5(2), pp. 173-197.

Bridger, J. C. (1996) Community imagery and the built environment, Sociological Quarterly, 3, pp. 353-374.

Brown, B. B. and Douglas, D. P. (1992) Disruptions in place attachment, in: I. Altman and S. M. Low (Eds) Place Attachment, pp. 279-304. New York: Plenum.
Childress, H. (1996) Place Attachment (edited) by Irwin Altman and Seth Low, The Journal of Architectural and Planning Research, 13(4), pp. 339-344.

Collier, P. (2004) Ireland's rurban horizon: new identities from home development markets in rural Ireland, Irish Journal of Sociology, 13(1), pp. 88-108.

Cuba, L. and Hummon, D. (1993) A place to call home: identification with dwelling, community and region, Sociological Quarterly, 34, pp. 111-131.

Cusk, R. (2006) Arlington Park. London: Faber and Faber.

Duffy, P. (2003) Change and renewal in issues of place, identity and the local, in: J. Hourihane (Ed.) Engaging Spaces: People, Place and Space from an Irish Perspective, pp. 13-29. Dublin: Liffey Press.

Fischer, C. (1982) To Dwell among Friends. Chicago, IL: Chicago University Press.

Francaviglia, R. V. (1996) Main Street Revisited. Athens, OH: University of Ohio Press.

Gans, H. J. (1962) The Urban Villagers. New York: The Free Press.

Gans, H. J. (1968) Urbanism and suburbanism as ways of life, in: R. E. Pahl (Ed.) Readings in Urban Sociology, pp. 95-118. New York: Pergamon Press.

Gieryn, T. F. (2000) A space for place in sociology, Annual Review of Sociology, 26, pp. 463-496.

Heidegger, M. (1978) Building, dwelling, thinking, in: D. F. Krell (Ed.) Martin Heidegger: Basic Writings, pp. 323-343. London: Routledge Kegan Paul.

Horgan, M. (2004) Anti-urbanism as a way of life, Canadian Journal of Irish Studies, 30(2), pp.38-47.

Hummon, D. M. (1990) Commonplaces: Community Ideology and Identity in American Society. Albany, NY: State University of New York Press.

Hummon, D. M. (1992) Community attachment: local sentiment and a sense of place, in: I. Altman and S. Low (Eds) Place Attachment, pp. 253-278. New York: Plenum Press.

Kelly, B. M. (1993) Expanding the American Dream: Building and Rebuilding Levittown. New York: State University of New York Press.

Kennett, P. and Forrest, R. (2006) The neighbourhood in a European context, Urban Studies, 43(4), pp. 713-718.

Kiberd, D. (1995) Inventing Ireland: The Literature of the Modern Nation. London: Jonathan Cape. 
Lupi, T. and Musterd, S. (2006) The suburban 'community question', Urban Studies, 43(4), pp. 801-818.

McManus, R. (2003) Urban dreams, urban nightmares, in: J. Hourihane (Ed.) Engaging Spaces: People, Place and Space from an Irish Perspective, pp. 30-44. Dublin: Liffey Press.

Molotch, H., Freudenburg, W. and Paulsen, K. E. (2000) History repeats itself, but how? City, character, urban tradition, and the accomplishment of place, American Sociological Review, 65, pp. 791-823.

Newby, H. (1979) Urbanization and the rural class structure: reflections on a case study, British Journal of Sociology, 30(4), pp. 475-498.

Pahl, R. E. (1968) The rural-urban continuum, in: R. E. Pahl (Ed.) Readings in Urban Sociology, pp. 263-297. Oxford: Pergamon Press.

Palen, J. J. (1994) The Suburbs. New York: McGrawHill.

Quilley, S. (2002) The house that Jack built, in: M. P. Corcoran and M. Peillon (Eds) Ireland Unbound: A Turn of the Century Chronicle, pp. 88-102. Dublin: Institute of Public Administration.

Relph, E. (1976) Place and Placelessness. London: Pion Press.

Riley, R. B. (1992) Attachment to the ordinary landscape, in: I. Altman and S. Low (Eds) Place Attachment, pp. 13-35. New York: Plenum Press.

Rowe, P. G. (1991) Making a Middle Landscape. Cambridge, MA: The MIT Press.

Sennett, R. (2000) New capitalism, new isolation: a flexible city of strangers, Le Monde Diplomatique, February.
Sibley, D. (1995) Geographies of Exclusion. London: Routledge.

Simonsen, K. (1997) Modernity, community or a diversity of ways of life: a discussion of urban everyday life, in: O. Källtorp, I. Elander, O. Ericsson and M. Franzen (Eds) Cities in Transformation: Transformation in Cities, pp. 162-183. London: Avebury.

Soja, E. W. (1996) Thirdspace: Journeys to Los Angeles and other Real-and-imagined Places. Cambridge, MA: Blackwell.

Tovey, H. (2002) Rethinking urbanisation: struggles around rural autonomy and fragmentation, in: M. P. Corcoran and M. Peillon (Eds) Ireland Unbound: A Turn of the Century Chronicle, pp. 167-185. Dublin: Institute of Public Administration.

Turkle, S. (1999) Cyberspace and identity, Contemporary Sociology, 28(6), pp. 639-647.

Vaiou, D. and Lykogianni, R. (2006) Women, neighbourhood and everyday life, Urban Studies, 43(4), pp. 731-743.

Varenne, H. (1993) Dublin 16: accounts of suburban lives, in: C. Curtin, H. Donnan and T. M. Wilson (Eds) Irish Urban Cultures, pp. 99-122. Belfast: Institute of Irish Studies.

Wellman B. (1979) The community question: intimate networks of East Yorkers, American Journal of Sociology, 84, pp. 1201-1231.

Wellman, B. and Hampton, K. (1999) Living networked on and off line, Contemporary Sociology, 28(6), pp. 648-654.

Williams, R. (1973) The Country and the City. New York: Oxford University Press.

Yates, R. (1961) Revolutionary Road. New York: Atlantic-Little, Brown. 